\title{
Patriarchy and marital disharmony amongst Nigerian Christians: Ephesians 5:22-33 as a response
}

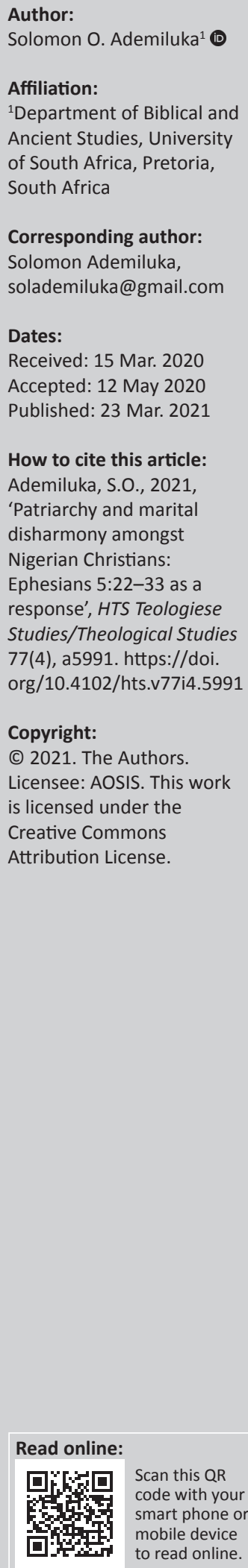

This article employs the descriptive and exegetical methods. It found several ways by which patriarchy precipitates marital disharmony in Nigeria. For instance, the custom of the bride price instils in the husband the feeling of ownership of the wife, which encourages some men to treat their wives like their property. The nature of marital disharmony varies with couples, but there are some common characteristics. The husband may withdraw from his wife, avoiding all forms of contact and communication with her; wife beating is also common. Ephesians 5:22-33 mitigates the patriarchal view of marriage, redefining the concepts of submission and leadership. The wife should submit to her husband's authority as she would to Christ whilst the husband should exercise his authority with love in imitation of Christ. When this new definition of marital relationship is understood and applied by Christian couples, disharmony will be considerably alleviated. The church should be involved in the application of the text, teaching husbands particularly the need to exercise their authority in sacrificial love.

Contribution: The article endorses the journal's focus on the combination of the notions 'source' and 'interpretation' by its emphasis on the exegesis of writings in the field of early Christian literature.

Keywords: patriarchy; marital disharmony; Pauline teaching; Nigerian Christians; the church.

\section{Introduction}

A large number of studies have been conducted on patriarchy, particularly as it engenders violence against women in Africa, and several of these studies are applied to the Nigerian context specifically (e.g. Ademiluka 2019; Agbonkhese \& Onuoha 2017; Babajide-Alabi 2017; Igbelina-Igbokwe 2013). These studies dwell on the fact that the abuse of women is inherent in patriarchy because, as a social system that is male-centred, it inevitably values men over women (Becker 1999:24). This article identifies ways in which patriarchal tendencies pose disharmony amongst Nigerian Christian couples and examines how Ephesians 5:22-33 can be applied as a remedy. The target groups are those Nigerian Christian couples whose relationships are in crisis arising from a patriarchal perception of marriage. The article employs a descriptive approach for the study of patriarchy and marital disharmony in Nigeria, and an exegetical method for the examination of the passage. It begins with the Ephesians 5:22-33 patriarchal tendencies in Nigeria and how they engender marital disharmony. Then, the article undergoes an exegesis of Ephesians 5:22-33 and finally applies the interpretation to alleviate marital disharmony amongst Nigerian Christians.

\section{Patriarchal tendencies in Nigeria}

The term 'patriarchy' is often traced to the Greek word patriarkhēs, meaning 'father of a race' or 'chief of a race'. Patriarchy therefore refers to 'the rule of the father' (London Feminist Network 2020:online). However, the term has gained wider connotations in modern times; hence, Merriam Webster (2020) defines patriarchy as:

$[A]$ social organization marked by the supremacy of the father in the clan or family, the legal dependence of wives and children, and the reckoning of descent and inheritance in the male line. (online)

According to Igbelina-Igbokwe (2013):

[Patriarchy] was originally used to describe the position of the father as a household head but it has progressively been used to refer to the systemic organization of male supremacy and female subordination ... [It] is a system of social stratification and differentiation on the basis of sex which provides material advantages to males while simultaneously placing severe constraints on the roles and activities of females; with various taboos to ensure conformity with specified gender roles. (online) 
Like most of African communities, the culture of most Nigerian ethnic groups is essentially patriarchal. Labeodan (2005:6) states that in 'most African societies male supremacy is ... taken for granted [with] [t] he ideology that men are naturally superior to women in essence and in all areas'. As Casimir, Chukwuelobe and Ugwu (2014) put it:

[I]n African societies, the traditional gender roles are usually maintained by a system of patriarchy which sees men as preeminent human beings and women as secondary whose roles are meant to complement those of men. (p. 170)

In Nigeria there are slight differences in male domination over women; for instance, in the northern part, Islam is the faith of the majority, and ' $t]$ his produces the living law - the rules that in reality, govern women's lives and determine the space within which they strategize for survival' (Igwe \& Akolokwu 2015:2). Nonetheless, generally, women are subjected to similar forms of gender prejudices and discrimination. In most parts of Nigeria, 'societal expectation of subservience of the female is a commonly accepted phenomenon' (Igbelina-Igbokwe 2013:online). Women's experience 'has been a long tale of discrimination and injustice ... as there has not been equity in the opportunity, dignity and power between men and women' (Familusi 2012:301). Effah and Onyegbula (1995:33) assert that in the patriarchal family, '[c]ustomarily, a woman and her children are [the] property of a man - the head of the family ...'. According to Igwe and Akolokwu (2015):

The family organization is a patriarchal one in which the male overshadows the female in respect of authoritative decisionmaking. ... [It] is the basic social unit where all [the] prejudices and discriminations ... are initiated, nurtured and practised. In the patriarchal family, [the] husband/father is the oppressor and dictator as the presumptuous head of the family and reduces wife/wives (mother) and, children to slaves. (p. 3)

Discrimination against the womenfolk begins with the girl child, to whom the male counterpart is often preferred; the major reason for this discrimination is that girls are 'perceived as expendable commodities who will eventually be married out to other families to procreate and ensure the survival of the spouses' linage by bearing sons' (Igbelina-Igbokwe 2013: online). This is a common belief amongst many of the ethnic groups, particularly the Igbo and the Yoruba of southeastern and southwestern Nigeria. Also, amongst the Benin people in the midwestern region, when female children are born, they (Osezua \& Agholor 2019):

$[A]$ re derogatorily referred to as 'half current', a vernacular terminology used to depict the perceived notion of less virility required to birth girls, and a direct cultural allusion to [their] inferior status. (p. 412)

In most ethnic groups, children are socialised into this notion of gender inequality; boys are trained and prepared for masculinity and acting in the public sphere, whilst girls are prepared for femininity, 'to identify with family and private sphere' (Igwe \& Akolokwu 2015:7).

Domination over women in marital relationship reflects right from the process of contracting traditional marriage in which the bride price is perhaps the most fundamental element. Culturally, the bride price serves as the mark of formal validation of a marriage, but unfortunately in a patriarchal culture it is deemed by many as the husband's 'certificate' of ownership of his wife and the children born by her in the contract. This belief accentuates the general notion that 'a wife is her husband's property to be inherited on his death', for instance, amongst the Igbo (Igwe \& Akolokwu 2015:6). According to Igbelina-Igbokwe (2013:online), 'the act of payment of bride price ... is perceived as an outright act of transfer of woman's rights in source family to spouse's family'. Hence, before and during wedding ceremony, the Yoruba woman, for example, is "taught that "oko ni olori aya" (the husband is the head of the wife), [and] this [she must be] prepared to accept' throughout her life (Ogoma 2014:101). At the wedding the woman is compelled by tradition to bear her husband's name as surname, dropping her father's name (Adeyemi 1998:52; cf. Labeodan 2005:9). From the wedding ceremony onwards, the new wife is given little regard by her husband's family. Writing on the Yoruba, Labeodan (2005) states:

[She is treated] as one of [their] possessions, voiceless, without rights, with constrained freedom and without her own identity (since she has to take up her husband's family name). She is treated ... by her in-laws with constraints; $[s]$ he is left to do all the house chores ... When it comes to social obligations such as meetings [and] ceremonies ... [she does] [t] he bulk of the preparation, cooking and cleaning ... She is forbidden to call anyone from her husband's side (extended family) by first name. She has to use ... coined names for [them] such as iyale (senior woman), baba oko (father/brother-inlaw), etc even if she's older than them. (p. 9)

In the Nigerian patriarchal system, the husband has physical control over his wife's body and its products in that 'children are viewed to belong to the [husband's] patrilineal family [in which case] [s] he is but a beast that produces the man's children on his behalf' (Labeodan 2005:6). In most of the ethnic groups in Nigeria, as in other parts of Africa, man has control not only over the woman's body but also over her sexuality. Masenya (2012:128) states that 'the sexuality of married women is perceived to be in the domain of the control of their husbands'. For instance, while a man is free to have a second wife or a concubine, 'the woman [even if she is a] second wife or concubine should always be faithful to one man' (Kealotswe 2009:302). With regard to men having several wives, the traditional Yoruba seem to believe that God made it so. Hence, they have a popular saying, which was produced into music by the renowned Yoruba musician, Ebenezer Obey, that (Alaba 2004):

Awa okunrin le laya mefa; ko buru; okunrin kan soso lOba Oluwa mi yan fobinrin. [We men can each have six wives; it is not bad at all! It is to only one man that my God has assigned a woman]. (p. 7)

In this way, African culture encourages men to contract polygamous marriages, but a woman who engages in extramarital relations is often condemned as an adulterer (Familusi 2012:304).

At the household level patriarchy reflects in gender role differentiation, or 'sexual division of labour brought about through societal socialization process. It is the assignment of 
status, role, duties, privileges and entitlements on the basis of sex' (Igwe \& Akolokwu 2015:7). Amongst the Yoruba, for instance, in the traditional setting (Alaba 2004):

[I]t is the duty of the woman to do all the work connected with the household other than carrying out repairs to the walls and roof of their house or hut ... The preparation and serving of food is one of the most exacting of her duties [but] in none of these does the Yoruba husband usually consider it his duty to lend a helping hand. (p. 5)

Apart from the natural role of childbearing, the woman performs duties prescribed to her by her husband, usually domestic roles. In the past, polygamy was the prevailing practice, with each wife being accorded rights as determined by the husband who was the lord of the house. The wives required his permission on virtually all issues, including 'movement, interaction as well as procreation' (Olajubu 1998, cited in Ademiluka 2018:350).

Olajubu (1998, cited in Ademiluka 2018:350) states that in the polygamous setting 'each wife had the additional and endless duty of seeking the husband's favour, sometimes by fighting with the other wives'. Nevertheless, it is important to note, as Ogoma (2014) rightly points out, that:

Yoruba women in the past never thought that it was a burden, or unfair treatment for them [for example] to cook for their husbands, even if they returned home [from work] at the same time. (p. 101)

In fact, tradition has it that a woman could hit her husband with a spoon if he came to the kitchen when she was cooking 'because that is not his area of jurisdiction' (Ogoma 2014:101). In modern times, the wife may not hit her husband with a spoon if found in the kitchen, but it is common that most Yoruba women are accustomed to doing all cooking alone without involving their husbands. It is worth mentioning that there are some untoward practices which amount to violence against women. For instance, in Nigeria, as in many parts of Africa, corporal punishment for wives 'is widely sanctioned as a form of discipline' (Aihie 2009:2). Hence, some men beat their wives in the name of 'instilling discipline in them ... [as women] are regarded as children who can be prone to indiscipline if not disciplined' (Agbonkhese \& Onuoha 2017:online). The next section illustrates how these patriarchal tendencies precipitate marital disharmony in Nigeria.

\section{Patriarchy as a cause of marital disharmony in Nigeria}

Many scholars have pointed out a clear connection between patriarchy and marital conflicts, in which women are at the receiving end most often. In other words, mistreatment of women usually occurs in traditional milieus that 'put women beneath men in status and personhood' (Gluck 2012:online). In the words of Becker (1999, cited in Ademiluka 2018):

$[T]$ he oppression of women is certainly an important part of patriarchy. $[A]$ social system that is male-identified, malecontrolled, male-centered will inevitably value masculinity and masculine traits over femininity and feminine traits. (p. 354)
Relating the subject to Africa, Okorie (2003:258) states that the African woman 'is always at the receiving ends of cultures and traditions which suppress, oppress, exploit, and abuse her'.

Baloyi (2010:2) identifies several elements of the African patriarchal culture that encourage domination of women, some of which have been mentioned in this study. As discussed earlier, in Nigeria, the custom of the bride price instils in the husband the feeling of ownership of his wife, which may encourage a man to treat his wife like a property. The feeling of ownership is accentuated, for instance, amongst the Yoruba, by teaching a woman before and during her wedding that 'oko ni olori aya' [the husband is the head of the wife], which she must be prepared to accept throughout her life (Ogoma 2014:101). Coupled with this teaching is the Yoruba view of marriage as an institution of learning through which the woman is expected 'to learn virtues [particularly] endurance and forbearance' (Bammeke \& Eshiet 2018:2). Apart from learning endurance, women are also taught to remain in marriage for the sake of their children, irrespective of their suffering. The older women would say, '[y]ou remain there because of your children. It is better to stay in a troubled home than in a broken home' (Bammeke \& Eshiet 2018:7). In this way, women domination in Nigeria can be correctly attributed to 'the traditional patriarchal values of the society' (Osezua \& Agholor 2019:416). Perhaps, it is these values that have led to the general perception of the subservience of women. According to Onegeria.com (2017), in this perception, the wife has to be a puppet to be the perfectly and completely submissive wife; like children, women are supposed to be seen not heard; the wife must do as the husband says. The wife must be 'all-round-the-clock homekeeper, nanny, cleaner, cook, sex slave' (Nigerian UNICORN 2017:online).

Marital disharmony arises in the course of the husband operating on this patriarchal view of marriage. Having paid the bride price, the husband feels that he owns his wife, and as marriage is an institution of continuous learning, he puts himself in the position of his wife's teacher; sometimes the teaching may take the form of scolding her like a child. Sometimes, these traditions become an 'entitlement syndrome [for some] men to dictate the terms of [e.g., sex] without due recourse for their spouses' (Osezua \& Agholor 2019:416). There are other areas in which men capitalise on the patriarchal perception of marriage to maltreat their wives. As discussed in this work, women should do all household chores including cooking, washing, cleaning and taking care of the children, whilst men go out for work to fend for the family. Conflict arises sometimes when the wife cannot or does not perform any of these duties for certain reasons, such as the nature of the wife's employment. Bammeke and Eshiet (2018:5) found in their study that amongst the causes of conflict between couples were 'the women's lateness from work [and] ... inability to give adequate child care because of long hours of work'. As patriarchy gives all authority to man, conflicts also ensue when the husband feels his authority is being challenged by his wife, for instance, when the wife argues with him or tries to correct him on certain issue (Bammeke \& 
Eshiet 2018:5). Another factor that often leads to marital disharmony is when changes arise and ' $[w]$ omen who were traditionally subservient and significantly dependent can now access critical resources ... [thereby] becoming breadwinners' (Osezua \& Agholor 2019:417). Osezua and Agholor (2019:417) found that such changes have served 'as triggers for family violence and instability' in many homes.

In discussing the role of the partners in marital disharmony, one must not have the impression that women are always passive whilst men are always the ones mistreating them. In fact, there are cases when it is the wife that is always on the offensive. However, in the Nigerian patriarchal system, most often women are at the receiving end. Thus, whilst the nature of the disharmony varies with couples, it has some common characteristics, which include (Amadi \& Amadi 2014):

$[W]$ ithdrawal by the husband who avoids all forms of contact and communication with the wife. Depending on the complexity of the situation, the withdrawal mode may manifest in [the] form of avoidance of physical contact or sex with wife, not talking to her and not eating at home. Other consequences include threats of divorce, confiscating equipment or materials related to wife's economic activities, locking wife out of the home, coming home late or not coming home for days. (p. 5; cf. Amadi \& Amadi 2014:135; Osezua \& Agholor, p. 416)

Amadi and Amadi (2014:134) add that when some couples have conflicts, they become 'addicted to their work yet others develop varying degrees of mental disorder including psychotic and psychopathological health conditions'. Amongst many couples, the disharmony involves physical violence against the wife, such as being slapped, pushed or shoved, hit with a fist, and/or being dragged and kicked, etc. (Osezua \& Agholor 2019:416). All of these come under wife beating, which some men view as a form of discipline; hence, it is the most common form of physical violence against women in Nigeria.

On the part of the women, oftentimes most of them want to abide by the teaching of endurance and forbearance, which explains the reluctance of [some] women to disclose their experience of abuse and their failure [even to] perceive certain behaviour as abusive' (Bammeke \& Eshiet 2018:7). For this reason, some women go through marriage in perpetual emotional stress, sometimes satisfying their husbands' demands only out of fear. For example, in the study carried out by Osezua and Agholor (2019:416), some 'women reported that they were [often] forced against their will [while others said] they had sexual intimacy with their spouses out of fear'. As part of such women's effort to make peace with their husbands (Bammeke \& Eshiet 2018):

[T]hey appealed to their husbands. When this failed to restore peace, they sought family intervention by reporting to family members[,] predominantly husband's parents and siblings or their own parents and other relations. (p. 5)

It is worth noting that Christians are not exempted from marital disharmony in Nigeria as discussed above. Rather, there are, in fact, reports of wife beating amongst Christians, even church elders and pastors, to the extent that several women have been beaten to death by these categories of Christians (Anenga 2017; Elekwa 2017; Fowowe 2015). Therefore, in the next section, the article does an exegesis of Ephesians 5:22-33, with a view to apply it to marital disharmony in Nigeria in the subsequent section.

\section{Ephesians 5:22-33 in relation to marital relationship: An exegesis}

Scholars usually divide the Epistle to the Ephesians into two main sections. According to Lovše (2009:120), the first section in Ephesians 1:1-3:21 discusses the new life which God has given to believers through Christ, while in the second section (Eph 4:1-6:24) the author expounds the new standards which God expects of his new society and new relationships into which God brings people'. As Marshall (2003:1385) puts it, Ephesians 'broadly discusses doctrine in the first half and then practical Christian living in its second half'. Ephesians 5:22-33 belongs to the literary unit in 5:22-6:9 written by the ancient Greek philosophers in 'order to uphold the power differential between husbands and wives, parents and children, and masters and slaves' (Mowczko 2019:online).

According to Lincoln (1990), philosophers had the notion that man was naturally intended:

$[T]$ o rule as husband, father, and master, and that not to adhere to this proper hierarchy is detrimental not only to the household but also to the life of the state. (p. 358)

In contrast, they had the conviction that women were inferior to men (Bristow 1991, cited in Lovše 2009:116). Hence, Aristotle and Plato taught absolute 'submission on the part of wives, while the role of the husband was ruling his wife' (Adams 2003:10). It has been suggested that the original purpose of the household codes was to safeguard possible erosion of the Roman family values, particularly by the spread of religions from the East such as Isis worship, Judaism and Christianity (Keener 1993:551). Mowczko (2019:online) explains that the 'Romans were suspicious of new groups, movements and religions that threatened social stability [and would] not tolerate what they saw as subversive teachers or disruptive groups'. Members of these minority religions, therefore, often tried to show their support for the Roman family values by using a standard form of household codes. Marshall (2003:1391) opines that from an early date the form 'became part of the regular teaching of the church'. To this end, in Ephesians 5:22-6:9, Paul borrows this pattern of writing but, as shown below, de-emphasises the absolute authority of the male head of the house.

In Ephesians 5:22-33, Paul enjoins wives to be subject to their husbands as they would to Christ. This is because the husband is the head of the wife just as Christ is the head of the church. Husbands must equally love their wives the same way Christ loved the church and gave himself up for her (vv. 22-25). Verses 26-32 expatiate on how Jesus loved the church, and in the same way husbands should love their wives. 
Verse 33 summarises by saying that each man should love his wife as himself, and the wife should respect her husband. It is important to note, however, that contrary to what is contained in the English translations, in Greek verses 22-24 form part of a single sentence which begins from verse 18, and forms one unit with verses 18-24. Turner (1994) states that, although obscured by all translations, verses 18-24:

[A]re grammatically a single sentence [which] means that the injunction to wives and husbands in 22-33 (along with the similar material which follows in 6:1-9) is presented as a typical example of the respectful, submissive wisdom that should characterize believers. (p. 1241; cf. Miles 2006:82)

Szesnat (2015:140) explains that the being filled with the Spirit in verse 18 is explored with three examples, namely, in singing psalms (Eph 5:19), giving thanks (Eph 5:20) and being subject to one another in reverence to Christ (Eph 5:21). Therefore, Szesnat (2015) states that:

The household codes that follow are grammatically and thematically subordinate to $5: 21$. This is underlined by the fact that the first sentence of the code (5:22) does not even have the verb ('submit'), though it is implied ... It is significant that many translations and commentators conclude the paragraph here, at the end of 5:21, and begin a new paragraph in 5:22. The problem with this common presentation is that the connection to the last example (the participial clause, 'being subject to each other') is easily lost, and that is highly problematic. (p. 140)

Other interpreters emphasise the fact that ' $[t]$ his transitional verse [v. 21] holds the key to the ... understanding' of what follows (Lovše 2009:121). This is because '[a]ll the household codes Paul proposes are based on' it (Keener 1993:551). In this regard, some believe that by virtue of verse 21, in the household code in Ephesians 5:22-6:9 Paul enjoins mutual submission across hierarchies. In other words, submission has to be reciprocal between husband and wife, parents and children, and masters and slaves. For instance, Miles (2006) asserts that:

[T] he injunctions for the submission of wives and the obedience of slaves and children are part of a general instruction that everyone - husbands/fathers/masters included - submit to or be subject to each other. (p. 77)

Keener (1993:551) also believes that because the verb of verse 22 is borrowed from verse 21 , 'it cannot mean something different [hence] in the Greek text, wifely submission to a husband (v. 22) is only one example of general mutual submission of Christians'. According to Marshall (2003:1391), 'this opening requirement [in v. 21] applies to everybody and means that submission and respect are to be shown by husbands, parents and masters'. Lovše (2009) recognises that the theme of submissiveness is often repeated in the Pauline texts with the notion of submission being used:

$[O]$ nly for the attitude of specific groups - women, children and slaves - or for the attitude of believers to the state.

However ... [here] the verb 'to submit' [is] employed for mutual relationships among believers. (p. 121)
In the opinion of Belz (2013:98), this implies that the submission of a Christian wife to her husband (v. 22) is dependent on his own submission to her: 'a wife's subordination to her husband is not unilateral but reciprocal'.

Nevertheless, it seems more plausible to suggest that the admonition in verse 21 is a general statement on submission which the author goes on to apply in detail to each group in the subsequent verses. In other words, he implies mutual submission amongst Christians but not necessarily across hierarchies. Contrary to Miles' (2006:77) claim that hupotasso [to submit] does not mean 'to obey', amongst the dictionary definitions of the word are 'to put in subjection, subject, subordinate, be subject, submit to, obey, be under the authority of, take a subordinate place' (The United Bible Society [UBS]) Lexicon, in Koehler, Baumgartner \& Stamm 1994-2000). Chapell (2009:297) is therefore correct when he says that the meaning of hupotasso 'requires submission of one person to another of greater authority'. Hence, in Ephesians 6:1-9 where Paul commands children to obey their parents and slaves to obey their masters, using the same root hupotasso, it is not likely that he means reciprocal obedience. That is to say, he could not imply 'parents, obey your children', for example. Therefore, in verse 22 the apostle does not likely mean reciprocal submission between the husband and wife. Bruce (1984) plausibly differentiates between the mutual submission in verse 21 and submission by someone of lower hierarchy to another of higher hierarchy in the subsequent verses. He writes (Bruce 1984):

While the household code is introduced by a plea for mutual submissiveness, the submissiveness enjoined in the code itself is not mutual. As in the parallel code in Colossians 3:18-4:1, wives are directed to be subject to their husbands, children to be obedient to their parents, and slaves to their masters, but the submissiveness is not reciprocated: husbands are told to love their wives, parents to bring up their children wisely, and masters to treat their slaves considerably. (p. 383)

Turner (1994:1242) recognises that 'the call for the wife to obey her husband was virtually a universal convention of Paul's world'. This is because it came not only from Paul himself severally but also from another apostle. Chapell (2009:293) also notes that 'Paul uses the same or related terminology about husbands and wives in at least five other books (1 Co, Eph, Col, 1 Tim, and Tit)'. In Colossians 3:18 and Titus 2:5, Paul counsels women to be subject to their husbands, adding in the latter epistle that they should do this so that no one will despise the word of God on account of their disobedience to their husbands. Similarly, Peter (1 Pt 3:1-2) 'gives instructions to the wives and confirms the same submissive attitude developed by Paul' (Lovše 2009:124). Chapell (2009:293) observes that in this passage Paul instructs wives three times (Eph 5:22, 24, 33) 'to subject their priorities to their husbands' authority'. Hence, Turner (1994) plausibly concludes:

Verse 21 should be taken ... as a call to mutual submission within each hierarchical level, and of children to parents; slaves to masters, and wives to husbands. Had Paul really meant a totally reciprocal submission (which would be entirely unexpected in the ancient world) he would have needed to clarify that by saying at least once, and explicitly, that, for example, parents should submit to children. (p. 1241) 
From these facts, it becomes clear that verse 22 demands submission from wife to husband, but not vice versa.

Verses 23 and 24 further dwell on wifely submission. The wife must submit to her husband because he is her head just as Christ is the head of the church (v. 23), and she must be subject to her husband in everything the same way the church is subject to Christ (v. 24). To understand wifely submission as demanded here, therefore, one has to have a proper grasp of what the writer means by husband being the head of his wife. Miles (2006) approaches this concept from the perspective of the meaning of the Geek word kephale [head]. He opines that the word literally means 'head' but does not have the English metaphorical connotations of 'ruler', 'leader' or 'one having authority over' the other. Neither can kephalē (Miles 2006):

[B]e translated as 'boss' or even as 'servant-leader' ... If Paul had meant 'boss' or 'leader' in his reference to man as head of the woman, he could have used arche, kyrios or despotis ['lord' or 'master']. (p. 82)

In his own view, Paul's use of kephalē is a metaphor referring to 'the power relations between the head and [the] body' (Miles 2006:83) as he employs it in other parts of this epistle, for example, Ephesians 1:22-23: and he has put all things under his feet and has made him the head over all things for the church, which is his body, the fullness of him who fills all in all (the Revised Standard Version, RSV). Miles (2006:83) understands 'head' in this passage literally as a reference to 'head' as it relates 'to the body, and not the idea of dominance and subordination'.

Nonetheless, Miles is incorrect that kephale does not have the metaphorical sense of a leader or one in authority over another. Thayer's Greek Lexicon (in Koehler et al. 1994-2000) states that metaphorically the term sometimes means 'master' or 'lord', citing the example of a husband in relation to his wife as in Ephesians 5:23. Citing 1 Corinthians 11:3, Friberg Lexicon (in Koehler et al. 1994-2000) also affirms that kephale is used metaphorically 'of persons, designating first or superior rank'. To this end, it is generally agreed that 'head' in Ephesians 1:22-23 refers to leadership. Lovše (2009:126) opines that the instruction to women in Ephesians 5:23 'intimates the notion of the headship of the husband', buttressing this point with Ephesian 1:22-23 where 'headship points to the concept of leadership'. Bruce (1984:384) also asserts that in Ephesians 5:23 'head' 'has the idea of authority attached to it after the analogy of Christ's headship over the church' (cf. Marshall 2003:1391).

Thus, in verses 23 and 24 Paul places the Christian wife under her husband's authority, for which reason some interpreters have accused him of being conservative and patriarchal, being the 'source of an infamous Christian injunction' that makes women subservient to men (Miles 2006:76). Some see the whole of the household code in Ephesians 5:22-6:9 'as the author's mirroring of [the ancient] codes to assure secular authorities of the respectability and conformity of Christian family life' (Miles 2006:76). As Adams (2003) puts it:
[T]here are other scholars who see Ephesians' employment of [the codes] ... as providing a veneer of conformity, so that Christian communities would at least appear less subversive, in order to survive in a hostile environment. (p. 26; cf. Keener 1992:142; Turner 1994:1241)

According to Dunnam (1982), today:

$[W]$ ithin the modern movement of women's liberation Paul is often seen as an oppressor - certainly a 'conservative' who championed the status-quo, subservient position of women, and allowed that position to be the norm within the church. (p. 225)

However, in accusing Paul of conservatism it is pertinent to note that he likens man's headship of his wife to Christ's headship of the church. The husband is the head of his wife as Christ is the head of the church (v. 23). It is therefore necessary to ascertain what Paul means by Christ being the head of the church in order to know how he views a Christian's authority over his wife. Already in verse 23, Paul gives a hint on this in saying that Christ is the head of the church, and he is its saviour. But the concept is fully developed in verses 25-27 where he describes the husband's duty towards his wife:

Husbands, love your wives, as Christ loved the church and gave himself up for her, that he might sanctify her, having cleansed her by the washing of water with the word, that he might present the church to himself in splendor, without spot or wrinkle or any such thing, that she might be holy and without blemish. (Revised Standard Version [RSV] Eph 5:25-27)

From this description, Christ's headship of the church involves loving the church up to the point of giving himself up for her, that is, dying for the church. In other words (Belz 2013):

Christ's love is synonymous with 'giving himself up'... It is a love of cost, of self sacrifice, a love which spends itself for the sake of the one loved ... [Moreover] Christ as head and savior loves his Church/body in such a way as to transform her into something glorious and resplendent, serving her needs as his beloved Church-Bride. [Having given] himself up for her, he washes her, makes her beautiful, warms her and nourishes her. (pp. 106, 126; cf. Turner 1994:1242)

It is in this manner that Paul expects Christian husbands to exercise their headship over their wives. 'The husband's headship or authority ... is one that is patterned on the unique character of Christ's headship over the Church' (Lovše 2009:127). Like Christ, husbands are to 'give themselves up' for the sake of their wives, which means that 'a husband who loves his wife as Christ loves his Church places a greater value on the life and well-being of his [wife] over even his own life' (Belz 2013:126). In the words of Miles (2006:86), 'Paul thus enjoined husbands to emulate Christ in sacrificing themselves for their wives, treating their wives with the same respect that they have for themselves'. In pragmatic terms, the Christian husband should be to his wife someone who is responsible, a protector, provider, lover, and a 'developer' (Lewis \& Hendricks 1991:63). Thus, a Christian husband's (Belz 2013): 
[L]ove for his wife is not to be self-serving, calculated for his own gratification or self-promotion; [rather], in imitation of Christ's own love for the Church, the Christian husband must be willing to lay down his life for his wife. (p. 127)

In verses 28-32, Paul concludes the husband-wife and Christchurch analogy of the marital relationship. At the centre of this section seems to stand the Old Testament concept of husband and wife becoming one flesh (v. 31), which the apostle quotes from Genesis 2:24. Because they are one flesh, the husband should consider loving his wife as loving his own body; he cannot afford to hate his own flesh, but rather should nourish and cherish it as Christ does the church. In verse 33, he caps the instruction, saying, 'let each one of you love his wife as himself, and let the wife see that she respects her husband' Eph 5:33, RSV. The word rendered 'respect' here is the Greek phobos, which literally means 'to fear'; however, the translation in this context is appropriate as the word can also mean 'respect, reverence or even adoration' (Lovše 2009:131).

Thus, contrary to the claim of some interpreters, as seen earlier, Paul's injunction on marital relationship in Ephesians 5:22-33 is more revolutionary than conservative or patriarchal. Paul addressed people in a stratified culture in which (Dunnam 1982):

$[P]$ ersons were bound into a certain 'station'[believed to be] the way the gods had created things ... This was especially true of women [who] were seen as chattel, things to be used at whims and fancy, without rights, little more than slaves. (p. 230)

As Miles (2006) puts it, the Graeco-Roman world of the 1st century was a society in which the motives for marriage were essentially patriarchal; it was one 'in which men took wives chiefly to serve their own needs for a legitimate heir and for household management' (Miles (2006:85). The ancient household codes that Paul adapted 'never listed love as a husband's duty [but] told husbands only to make their wives submit' (Keener 1993:552). Therefore, while Paul upheld the traditional ideal of wifely submission, in urging that a man should care about his wife, he did not only 'seriously [challenge] patriarchal motives for marriage' but, in fact, went far beyond such values (Miles 2006:85; cf. Keener 1993:552). As against the old order in which men were 'expected to be virile [and] dominant, [in Eph 5] husbands are to nourish and cherish their wives' (Miles 2006:86). Therefore, as Turner (1994) plausibly asserts:

[T]o affirm that the marital codes [in Ephesians] are more socially conformist than revolutionary would be misleading ... [Rather], within the hierarchical social order they uphold they were radical and profoundly liberating; Ephesians brings a particularly radical new Christian understanding to marriage. (p. 1241)

In this new understanding, Paul mitigates the patriarchal view of marriage; the wife submits to her husband as one who has authority over her, but the Christian husband exercises his authority in love that is as profound as that of Christ in laying down his life for the church. Thus, as against the patriarchal system, in this new understanding of marriage the husband's role is focused more on love and self-denial than on authority. In the following section, the article applies Ephesians 5:22-33 as a response to marital disharmony amongst Nigerian Christians from this perspective of the husband laying down his own rights for the sake of his wife in imitation of Christ.

\section{Ephesians 5:22-33 as a response to marital disharmony amongst Nigerian Christians}

As this study has shown, marital disharmony is caused by the patriarchal perception by which women as humans are considered lower to men in status, by virtue of which belief a man looks upon his wife as a property rather than as a partner. Under this patriarchal perception of marriage, submission on the part of the wife means acceptance of total domination by her husband and his family. Applying Ephesians 5:22-33, therefore, demands a change in this perception and a redefinition of submission and leadership. In accordance with the text as interpreted here, the wife submits to her husband's authority as she would to Christ, whilst the husband exercises his authority in love, laying down his own rights for the sake of his wife in imitation of Christ. Moreover, according to the passage, husband and wife are one flesh; therefore, the husband's love for his wife should translate to nourishing and cherishing her like his own body. In applying the passage to solve the problem of marital disharmony in Nigeria, this new definition of leadership will have to modify the husband's attitude towards his wife in several ways. In the first place, the perception of headship in the patriarchal family causes disharmony. The husband is the master and lord over his wife and children, and the wife does not dare to argue with him or attempt to correct him on any matter; if she does, a quarrel ensues. The figure of the family head in Ephesians 5 is different from this; he is the one controlled by profound love, in imitation of Christ who emptied himself and assumed the form of a servant (cf. Phlp 2:6-7).

When marital relationship is viewed from the perspective of Ephesians 5, the bride price is no longer seen as conferring on the husband the ownership of his wife but rather a traditional indication of the willingness of the bride's parents' consent in the marriage, which serves as a bond of love between the two families. Rather than seeing the wife as a property on account of the bride price, it now serves as a reminder to the husband to treat his wife with love as a sign of respect and gratitude to his in-laws. The Yoruba has this social concept of marital relationship in the saying, 'Eni funni l'omo pari oore' [giving one's daughter in marriage is the acme of goodness]. In the patriarchal system, the wife should do all household chores, and disharmony arises when she is not able to perform certain duties, perhaps because of other works which are also for the upkeep of the family. When Ephesians 5:22-33 is properly understood and applied, this situation no longer will cause conflict in the home because submission as now understood does not turn the wife into a house maid. The head of the wife portrayed by Paul is one that seeks the pleasure and comfort 
of his wife over his own and understands when his wife needs help and readily gives a helping hand. Also, in a family where the husband has the patriarchal perception of marriage, disharmony arises if the wife has some economic upper hand because she may not be submissive to her husband anymore. In this type of situation, Ephesians 5 demands that the wife should remain subject to her husband as she is to Christ, and must respect him (vv. 24, 33). Moreover, the concept of husband and wife being one flesh (v. 31) implies that whatever one has belongs to both. Hence, in view of the text, difference in socio-economic status should not bring about any conflict in the home.

Thus, a proper appropriation of Ephesians 5:22-33 will go a long way in alleviating marital disharmony amongst the Nigerian Christians. In the words of Lincoln (1993, cited in Adams 2003):

[The appropriation will] ... bring to bear on the marriage conventions what [Paul] held to be the heart of the Christian message ... [Paul had a view of marriage] where love ensures that the relationship does not degenerate into a sterile competition for control ... [Rather] [s]ubmission and love [are] ... seen as two sides of the same coin - unselfish service of one's partner. (p. 83)

Finally, in applying Ephesians 5:22-33 to ensure marital harmony in Nigeria, the church has a crucial role to play.

It is true that some denominations engage intending couples in marriage induction courses, but they are left to themselves after the wedding. Most churches also give sermons on marital relationship during wedding ceremonies, but such sermons are usually on love and submission, and often in conformity with the patriarchal assumption on submission. The church needs to go deeper on the concept of husbands' headship; husbands need to be taught that their authority should be exercised in the manner of sacrificial love in imitation of Christ.

Moreover, it is inadequate to limit teaching on marital relationship to pre-wedding induction courses and wedding sermons. It will be helpful for couples if the church organises regular teaching on sustaining marital harmony, using the Ephesians text amongst others. Such teachings may be incorporated into all the church manuals and administered to all categories of members. Teaching on marital relationship is particularly important for the younger generations who should be taught to begin to move away from the patriarchal perceptions of marriage.

\section{Conclusion}

This article found several ways by which patriarchy precipitates marital disharmony in Nigeria. For instance, the custom of the bride price instils in the husband the feeling of ownership of his wife, which encourages some men to treat their wives like their property. The teaching that marriage is an institution of learning for women makes the husband to assume the position of his wife's teacher, and sometimes the teaching may take the form of scolding her like a child. In a patriarchal family the wife does all the household chores, and conflict often arises when for certain reasons she is not able to perform some duties. As patriarchy gives all authority to men, conflicts also ensue when the husband feels his authority is being challenged by his wife, for instance, when the wife argues with him or tries to correct him on certain issue. The nature of marital disharmony varies with couples, but there are some common characteristics. Examples include the following: the husband may withdraw from his wife, avoiding all forms of contact and communication with her; he may stop talking to her and may also not eat at home for some time.

Some men stay away from the house for days or come home late. Some confiscate their wives' equipment or issue threats of divorce. Wife beating is very common. In Ephesians 5:22-33, Paul mitigates the patriarchal view of marriage, redefining the concepts of submission and leadership. The wife should submit to her husband's authority as she would to Christ, whilst the Christian husband should exercise his authority with love in imitation of Christ laying down his life for the church. In this way, the husband's role is focused more on love and self-denial than on authority. Moreover, husband and wife are one flesh; therefore, the husband's love for his wife should translate to nourishing and cherishing her like his own body. When this new definition of marital relationship is understood and applied by Christian couples, disharmony will be considerably alleviated. In the first place, the attitude of the husband as the family head is now controlled by sacrificial love. He does not assume the position of an authoritarian, unapproachable husband any longer. For him, the bride price is no more a certificate of ownership of his wife but serves as a bond of love between him and his wife's family. Submission as now understood by him does not turn the wife into a house maid, as he understands when she needs help and readily gives a helping hand. Now understanding that they are one flesh, difference in socio-economic status would not bring any conflict between the husband and wife because whatever one has belongs to both. Finally, the church in Nigeria has to be involved in applying Ephesians 5:22-33 to Christian marital relationships. The church needs to regularly engage married members in teaching on sustaining harmony. Husbands particularly need to be taught to exercise their authority in the manner of sacrificial love like that of Christ.

\section{Acknowledgements Competing interests}

The author has declared that no competing interests exist.

\section{Author's contributions}

I declare that I am the sole author of this research article.

\section{Ethical considerations}

This article followed all ethical standards for a research without direct contact with human or animal subjects. 


\section{Funding information}

This research received no specific grant from any funding agency in the public, commercial or not-for-profit sectors.

\section{Data availability}

Data sharing is not applicable to this article as no new data were created or analysed in this study.

\section{Disclaimer}

The views and opinions expressed in this article are those of the author and do not necessarily reflect the official policy or position of any affiliated agency of the author.

\section{References}

Adams, D., 2003, 'The transformative ethos of Ephesians 5:21-33 and its implications for a contemporary South African context', MA thesis, University of Stellenbosch.

Ademiluka, S.O., 2018, 'Patriarchy and women abuse: Perspectives from ancient Israel and Africa', Old Testament Essays 31(2), 339-362. https://doi.org/10.17159/2312 3621/2018/v31n2a5

Ademiluka, S.O., 2019, 'A study of 2 Samuel 13:1-22 as a solution to intimate partner violence in Nigeria', Journal for Semitics 28(2), 1-20. https://doi.org/10. 25159/2663-6573/3751

Adeyemi, L., 1998, 'The Yoruba cultural values and the ideology of feminism', in R. Ajayi, O. Alana \& Y. Akinwumi (eds.), Multi-disciplinary perspectives in Nigerian studies, pp. 49-58, Nathadex, llorin.

Agbonkhese, J. \& Onuoha, C., 2017, 'Does Nigerian culture permit domestic violence?', Vanguard, 24 August 2017, viewed 12 December 2017, from https://www. vanguardngr.com/2017/08/nigerian-culture-permit-domestic-violence/.

Aihie, O.N., 2009, 'Prevalence of domestic violence in Nigeria: Implications for counseling', Edo Journal of Counselling 2(1), 1-8. https://doi.org/10.4314/ejc. v2i1.52648

Alaba, O., 2004, Understanding sexuality in the Yoruba culture, pp. 1-13, Africa Regional Sexuality Resource Centre, viewed 31 January 2020, from https://www. arsrc.org/downloads/uhsss/alaba.pdf.

Amadi, U.P.N. \& Amadi, F.N.C., 2014, 'Marital crisis in the Nigerian society: Causes, consequences and management strategies', Mediterranean Journal of Social Sciences 5(26), 133-143. https://doi.org/10.5901/mjss.2014.v5n26p133

Anenga, U., 2017, 'The role of the church in marriage', The Guardian, 26 November 2017, viewed 13 July 2018, from https://guardian.ng/opinion/role-of-the-churchin-marriage/.

Babajide-Alabi, M., 2017, 'Let's talk about rape', Vanguard, 17 September 2017, viewed 01 December 2017, from https://www.vanguardngr.com/2017/09/letstalk-rape/.

Baloyi, E.M., 2010, 'A re-reading of John 8:1-11 from a pastoral liberative perspective on South African women', HTS Teologiese Studies/Theological Studies 66(2), 1-7. https://doi.org/10.4102/hts.v66i2.838

Bammeke, F. \& Eshiet, I., 2018, 'Issues in marital conflict and violence: Sociological analysis of narratives of selected Yoruba women', Crawford Journal of Business \& Social Sciences 3(2), 1-8.

Becker, M., 1999, 'Patriarchy and inequality: Towards a substantive feminism', The University of Chicago Legal Forum 1(3), 21-88.

Belz, L.M., 2013, 'The rhetoric of gender in the household of God:Ephesians 5:21-33 and its place in Pauline tradition', PhD dissertation, Loyola University, Chicago, IL.

Bristow, J.T., 1991, What Paul really said about women, Harper Collins Publishers, San Francisco, CA.

Bruce, F.F., 1984, The epistles to the Colossians, to Philemon, and to the Ephesians, WB. Eerdmans Publishing Company, Grand Rapids, MI.

Casimir, A., Chukwuelobe, M.C. \& Ugwu, C., 2014, 'The church and gender equality in Africa: Questioning culture and the theological paradigm on omen oppression',
Open Journal of Philosophy 4(2), 166-173. https://doi.org/10.4236/ ojpp.2014.42024

Chapell, B., 2009, Ephesians, P\&R Publishing Company, Phillipsburg, NJ.

Dunnam, M.D., 1982, The preacher's commentary: Galatians, Ephesians, Philippians, Collosians, Philemon, Thomas Nelson Publishers, Nashville, TN.
Effah, J.D.M. \& Onyegbula, S., 1995, Unequal rights; discriminatory laws and practices against women in Nigeria, Constitutional Right Project, Lagos.

Elekwa, E., 2017, 'Nigeria: Ex-boxer on the run for beating wife to death over Xmas food', Daily Trust, 29 December 2017, viewed 14 July 2018, from https://allafrica. com/stories/201712290459.html.

Familusi, O.O., 2012, 'African culture and the status of women: The Yoruba example', The Journal of Pan African Studies 5(1), 299-313.

Fowowe, P., 2015, 'My Pastor beats his wife ... how can I help?' The Cable, 03 August 2015, viewed 15 July 2018, from https://www.thecable.ng/pastor-beats-wife-can-help.

Gluck, S., 2012, 'Causes of domestic violence, domestic abuse', Healthy Place, viewed 13 March 2020, from https://www.healthyplace.com/abuse/domestic-violence/ causes-of-domestic-violence-domestic-abuse.

Igbelina-lgbokwe, N., 2013, 'Contextualizing gender based violence within patriarchy in Nigeria', Pambzuka News: Voices for Freedom and Justice, 12 pages, viewed 28 January 2018, from https://tinyurl.com/ycmmoy2g.

Igwe, O.W. \& Akolokwu, G.O., 2015, 'Patriarchy and its violations of human rights of women in Nigeria', International Law and Policy Research Journal 1(1), 1-8.

Kealotswe, O.N., 2009, 'Biblical and African forms of marriage and Old Testament prophecy: An interpretation of Isaiah 4:1 in the era of HIV/AIDS by an African independent church leader in Botswana', Theologia Viatorum: Journal of Theology and Religion in Africa 33(3), 296-321.

Keener, C.S., 1992, Paul, women and wives: Marriage and women's ministry in theletters of Paul, Hendrickson, Peabody, MA.

Keener, C.S., 1993, The IVP bible Leicester commentary: New Testament, Inter Varsity Press, IL.

Koehler, L., Baumgartner, W. \& Stamm, J.J., 1994-2000, Hebrew and Aramaic lexicon of the Old Testament, translated and edited under supervision of M.E.J. Richardson, 2003 edn., Bible Works 6, Koninklijke Brill, Leiden.

Labeodan, M.O., 2005, 'The family lifestyle in Nigeria', Princeton Education papers, viewed 12 January 2020, from https://paa2005. princeton.edu/papers/51248.

Lewis, R. \& Hendricks, W., 1991, Rocking the roles, NavPress, Colorado Springs, CO.

Lincoln, A.T., 1990, Ephesians, Word Books, Dallas, TX.

Lincoln, A.T., 1993, 'The theology of Ephesians', in Lincoln A.T. \& WedderburnA.J.M. (eds.), New Testament theology: The theology of the later Pauline letters, pp. 73-166,Cambridge University Press, Cambridge.

London Feminist Network, 2020, 'What is patriarchy?', London Feminist Network, viewed 05 March 2020, from https://tinyurl.com/y7yzrgzc.

Lovše, N., 2009, 'Roles of husbands and wives in the Christian marriage relationship (Ephesians 5)', KAIROS - Evangelical Journal of Theology III(2), 113-134.

Marshall, H., 2003, 'Ephesians', in J.D.G. Dunn (ed.), Eerdmans' commentary on the Bible, pp. 1385-1393, WB. Eerdmans Publishing Company, Grand Rapids, MI.

Masenya, J.M., 2012, 'Drippling nails, desire and polygynous partnerships: Navigating women's stories in Genesis 29-30 through African love song(s)', Theologia Viatorum: Journal of Theology and Religion in Africa 36(1), 125-140.

Miles, C.A., 2006, 'Patriarchy or gender equality? The letter to the Ephesianson submission, headship, and slavery', Dialogue: A Journal of Mormon Thought 39(2), 70-95.

Mowczko, M., 2019, 'The household codes are about power, not gender', Marg Mowczko: Exploring the biblical theology of Christian egalitarianism, viewed 11 January 2020, from https://margmowczko.com/household-codes-power-notgender/.

Ogoma, D.E., 2014, 'Reflection on an African traditional marriage system', Journal of Social Sciences and Public Affairs 4(1), 94-104.

Okorie, A.M., 2003, 'Biblical studies and women issues: Marriage', in S.O. Abogunrin (ed.), Biblical studies and women issues in Africa, pp. 255-267, Nigerian Association for Biblical Studies, Ibadan.

Olajubu, O., 1998, 'Culture as an empowering tool in Africa: A feminist perspective', in R. Ajayi, O. Alana \& Y. Akinwumi (eds.), Multi-disciplinary perspectives in Nigerian studies, pp. 60-69, Nathadex, Ilorin.

Onegeria.com, 2017, 'What most African men actually mean by submission in marriage', Onenigeria, 20 March 2017, viewed 12 January 2020, from https:// onegeria.com/2017/03/submission-to-most-african-men.html.

Osezua, O.C. \& Agholor, H.N., 2019, 'Patriarchy, cultural prejudices and spousal violence in the ancient city of Benin of southern Nigeria', Journal of International Women's Studies 20(7), 409-422.

Szesnat, H., 2015, 'Gender-based violence and Ephesians 5: Reflections on the ethics, hermeneutics and didactics of a community bible study in Suva, Fiji', in F. Nokise $\& \mathrm{H}$. Szesnat (eds.), Oceanic voyages in theology and theological education: $\&$. Szesnat (eds.), Oceanic voyages in theology and theological education:
Reflections and reminiscences in celebration and the 50th anniversary of Pacific Theological College, pp. 133-168, Pacific Theological College, Suva.

Turner, M., 1994, 'Ephesians', in D.A. Carson, G.J. Wenham, J.A. Motyer \& R.T. France (eds.), New Bible commentary, pp. 904-945, Inter Varsity Press, Nottingham.

Webster, M., 2020, 'Patriarchy', Merriam Webster dictionary, viewed 13 March 2020, from https://tinyurl.com/y6wpaenl. 